\title{
Liliaceae of Dr. Hayata's Indo-Chinese Collection
}

\author{
by Tetsuo KoYama* \\ 小山鐵夫*：早田教授採集のインドシナ應ユリ科植物
}

Received June 18, 1958

This paper deals with the liliaceous specimens left unidentified by the late Dr. B. Hayata in the herbarium of the University of Tokyo (TI). His ample Indo-Chinese cellections were made during his long trips to the Indo-Chinese peninsula in three times; according to his diary, he was in Tonkin from June to August in 1917, in Annam from May to June in 1921, and in Siam from September to December in 1921. He also visited Yünnan briefly in the first trip. I originally intended to identify only the sedges of the collection for a monograph of the Cyperaceae in Asia, but lately some collections from Himalayas were brought to Japan, and in the course of the determination of these plants, the need was felt to have Hayata's Indo-Chinese plants determined. The first paper comprising the taxonomic treatment of Cyperaceae of that collection was published in Contributions de l' Institut Botanique de l'Université de Montréal 70:5-64. 1957, while the second including Xyridaceae and Eriocaulaceae appeared in the Philippine Journal of Science 84 (3):365-378. 1956. In Hayata's collection containing mostly lowland species, the Liliaceae is not very abundant, however, there are some isotypes described by Gagnepain in Le Bulletin de la Société Botanique de France 84: 1934, since E. Lagrange, who accompanied him in his last trip, brought a part of the collection back to the Herbarium of Muséum d'Histoire Naturelle de Paris (P).

1. Asparagus acerosus Roxb., F1. Ind. ed. 1, 2: 150 (1820); Baker in Journ. Linn. Soc. 14: 622 (1875); Hook. f., F1. Brit. Ind. 6: 317 (1892); Gagnep. in H. Lecomte, F1. Génér. Indo-China 6: 778 (1934).

A n n a m: Ninhoa. B. Hayata. 392.-India, Malaysia, Australia.

Species well characterized by its elongate racemes 2 to $7 \mathrm{~cm}$. long.

2. Asparagus cochinchinensis (Lour.) Merrill

T o nk in: Tamdao. B. Hayata, sin. num.-China, Korea, Japan.

3. Asparagus filicinus Hamilt. ex D. Don, Prodr. 49 (1825).

A n n a m: Dalat. B. Hayata, sin. num.-China, India.

4. Chlorophytum orchidastrum Lindley.

S i a m: Doi Sutep. B. Hayata. sin. num, ; entre Pong Pa Pow et Pong Kioh. $B$. Hayata, sin. num.-Africa, India, China.

5. Dianella ensifolia DC. ex Redouté.

* Botanical Institute, Faculty of Science, University of Tokyo 東宗大学理学部植物学教室 
A n n a m: Dalat. B. Hayata, 92.-Madagascar, India, Malaysia, Formosa, Ryukyus, Japan.

6. Dispozum cantoniense (Lour.) Merrill; Kitamura in Kihara, Fauna \& F1. Neplal Himal. 92 (1955).

A n n a m: Dalat. B. Hayata, 196.-India, Malaysia, Formosa, Japan.

7. Disporum tonkinense T. Koyama, spec. nova a Disporo sessili D. Don floribus multo minoribus vix $1 \mathrm{~cm}$. longis et a Disporo cantoniesi Merrill foliis ellipticis ovaribusve, habitu minore distincte recedit-Fig. 1.

Perennis, rhizomate lignoso breviter repente, radicibus validis $1 / 2-4 \mathrm{~mm}$. crassis fusco-cinnamomeis. Caulis gracilis 2-4 $\mathrm{dm}$. altus simplex vel sursum laxe dichotomi-ramosus basi vaginis $2-5$ spathaceis membranaceisque $2-6 \mathrm{~cm}$. longis fuscorubentibus apice obtusis vestitus. Folia remote alternata ad unicum caulem 3-7 sessilia elliptica vel ovalia $2.5-6 \mathrm{~cm}$. longa 1.5-3 cm. lata membranacea 3-5-nervia margine integra apice basique abrupte breviter acuta. Umbella laxe 3-5-flora sessilis vel brevissime (1-2 mm.) pedun-

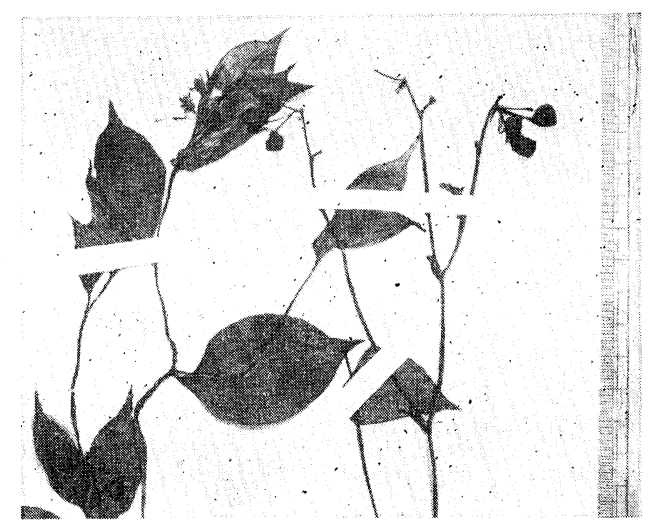

Flg. 1. Disporum tonkinense T. Koyama (Holotype) culata, pedicellis obliquis $9-13 \mathrm{~mm}$. longis.

Flores albi circiter $9 \mathrm{~mm}$. longi; tepala exteriora ovato-elliptica 6-7 mm. longa trinervosa apice rotunda atque mucronata in anthesi sursum patentia usque recurva; tepala interiora exterioris similia sed leviter angustiora longioraque; stamina 6 tepalis longiora, filamentis compressis $6 \mathrm{~mm}$. longis, antheris oblongis $2.5 \mathrm{~mm}$. longis ; pistilum cum staminibus aequilongum apice trifidum, ovario $1.5 \mathrm{~mm}$. longo ellipsoideo. Bacca globosa 6-9 mm. in diametro maturitate sordide caerulens; seminibus ovoideis facie opacis $4 \mathrm{~mm}$. longis ac latis.

To n k in: Tamdao. B. Hayata, sin. num.-holotypus in TI.

Closest to D. cantoniense, but differing therefrom in having broadly elliptical, light green leaf-blades.

8. Disporum trabeculatum Gagnepain in Bull. Soc. Bot. Fr. 81: 286 (1934) et in H. Lecomte, F1. Génér. Indo-Chine 6: 783 (1934).

T o n k i n: Chapa. B. Hayata, sin.num.; Tamdao. B. Hayata, sin. num.-Endemic in Indo-China.

This species is also known from Annam; quite distinct secondary nervules transversely connecting longitudinal nerves on large broadly oval leaves clearly distinguish this one from all other members of this genus.

9. Gloriosa superba Linn.

S i a m: Xen Mai. B. Hayata, sin. num.--Rather widely extending in the tropical 
regions of the Old World from northern Africa through India to Malaysia.

10. Gonioscypha muricata Gagnepain in Bull. Soc. Bot. Fr. 81: 287 (1934) et in Lecomte, F1. Génér. Indo-Chine 6: 803, f. 79, 1-5 (1933).

S i a m; Doi Stuep. B. Hayata, sin. num.

New to the flora of Siam, previously known only from Laos, where this was first described. The genus Gonioscypha is a small southern Asiatic genus including only two species of very strange look. Another species is G. eucomoides Baker of Himalaya, bearing dark green flowers. In our plants, flowers are whitish in the tubular part and blackish purple on segments. Gagnepain (11. cc.) described perianth tubes as $3 \mathrm{~mm}$. wide, but in the above specimen, they are about $7 \mathrm{~mm}$. across.

11. Hemerocallis longituba Miquel.

Y ün na n: Yünnanfou. B. Hayata, sin. num.-Formosa. Japan.

This specimen well coincides with Japanese common form of $H$. longituba, which may be specifically distinct from European $H$. fulva in the longer perianth tube always 2.5-3 cm. long.

12. Heterosmilax japonica Kunth, Enum. P1. 5: 270 (1850); T. Koyama in Quart. Journ. Taiwan Mus. 10: 20 (1957).

H. dalatensis Gagnep. loc. cit. 81: 69 (1934), ex isotypo-Smilax planipedunculata Hayata-H. arisanensis et raishaensis Hayata.

A n na m: Dalat. B. Hayata, 768-type of H. dalatensis Gagnep. in P, isotype in TI.-Formosa, Ryukyus.

Gagnepain described $H$. dalatensis laying stress on its oblong perianth, which is a relatively rare occurrence in the continental species of this genus, on the other hand, however, oblong connate perianth minutely 3-toothed at the apex characterizes H. japonica Kunth itself!

13. Heterosmilax polyandra Gagnepain in Bull. Soc. Bot. Fr. 81: 70 (1934) et in H. Lecomte, F1. Génér. Indo-Chine 6: 775, f. 73 (1934).

T o n k i n: Tamdao. B. Hayata, sin. num.-Endemic in Indo-China.

This plant has hitherto been known only from Laos. There is a little hesitation in identifying this specimen with $H$. polyandra from Laos, since the speimen is not quite perfect and lacks the male flower. Further in our specimen, leaf-blades are not cordate at the base but rounded.

The polyandry ( 9 to 12 to a flower) seen in this species characterizes the section Pseudosmilax (Hayata) T. Koyama, in which are described two more species, viz. $H$. seisuiensis Wang et Tang, and H. hogoensis Hayata, the latter being considered to be identical with the former (cf. T. Koyama, op. cit. 21. 1957).

14. Ophiopogon latifolius L. Rodrigues in Bull. Soc. Bot. Fr. 75 : 998 (1929)-Fig. 2.

To n k i n: Tamdao. B. Hayata, sin. num.-Endemic in Tonkin.

Very stiff broad leaves gradually narrowed below to a petiole-like base well define this strange looking species, which seems to be near to O. dracaenoides Baker of Himalaya. Besides this one, two new species, O. subverticillatus Gagnep ex 
L. Rodr., and O. tonkinensis L. Rodr., were published in the same place, however, none of these was included in Flore géneéral de 1'Indo-Chine tomé 6 by Gagnepain (1934).

15. Polygonatum laoticum Gagnepain in Bull. Soc. Bot. Fr. 81: 288 (1934) et in H. Lecomte, F1. Génér. IndoChine 6: 794 (1934).

Stem robust, simple, $3-6 \mathrm{dm}$. tall, obtuse-angled; leaves 7 to 13 to a stem, alternate, elliptical of ovate-oval, membraneous, suddenly contracted to sessile or shortly petiolate (up to $5 \mathrm{~mm}$. lg.) base apex abruptly attenuate and shortcaudate; flowers in groups of 2 to 3 disposing in sessile axillary umbel ; berries 6 to $12 \mathrm{~mm}$. across, blue-black seeds 1 to 5 in a berry.

A n nam: without definite locality. B. Hayata, sin. num.

As this specimen lacks the flower, I am not quite sure that this plant is quite correctly identified.

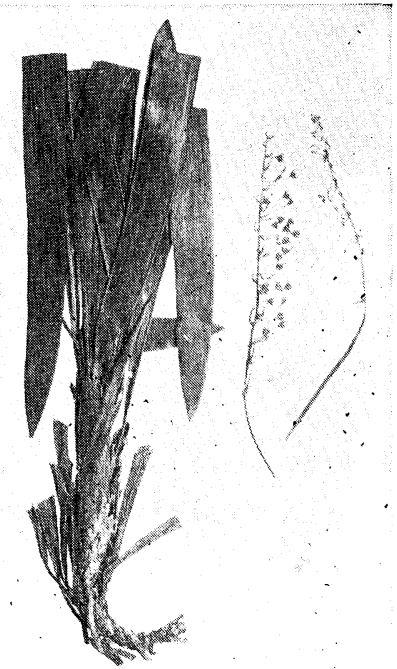

Fig. 2. Ophiopogon latifolium L. Rodr.

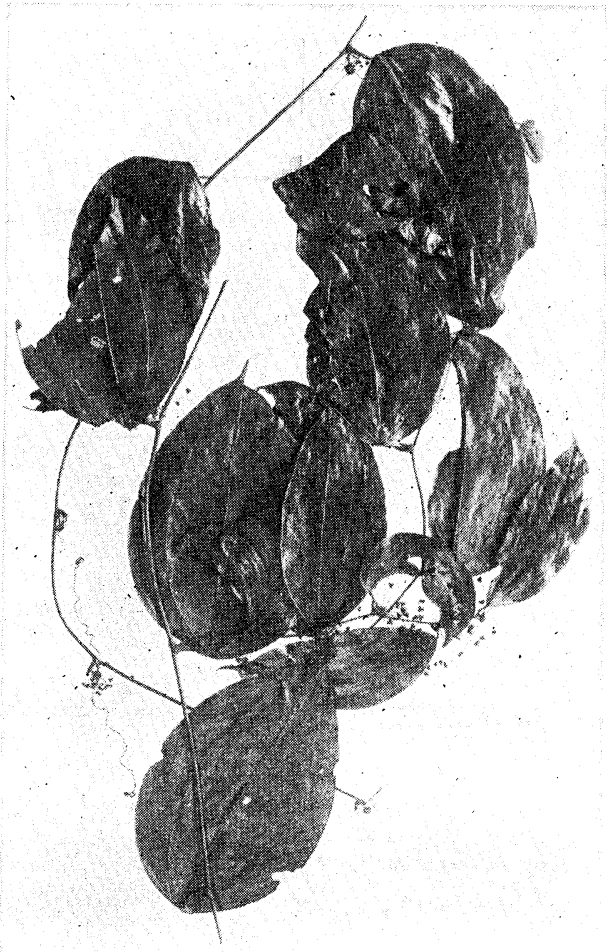

Fig, 3. Similax brevipes T. Koyama (Holotype.)
16. Smilax brevipes T. Koyama, spec. nova ex affinitate Smilacis siderophyllae H.Mazz. differt a qua ramis non costatis, umbellis semper simplicibus unicis petiolo multo brevioribus, et a Smilaci camboaiana Gagnep. recedit pedunculis umbellarum basi non squamatis, ramis ramulisque laevissimis. Sect. Coilanthus DC.-Fig. 3.

Liana sempervirens, caulibus graciliter elongatis teretibus laevissimis. Folia remote alternata; laminae oblongo-ellipticae usque ovales $5-15 \mathrm{~cm}$. longae $2-9 \mathrm{~cm}$. latae coriaceae supra nitidae subtus opacae sed non cinereae basi abrupte contractae rotundae apice etiam rontundae cum acumine abrupte acuto, nervis principalibus longitudinalibus 3 convexis nervulis lateralibus fertenuibus obliquis reticulationes minutas formantibus; petioli $10-15 \mathrm{~mm}$. longi laeves infra medium alati; claviculae breves cum petiolo suo aequilongae. Umbellae solitariae simplices subsessiles dense plus quam 30-florae, pedunculo tereti 3-7 $\mathrm{mm}$. longo ebratcteato 1/3-1/4 petiolum aequilongo, pedicelis capi- 
llaribus ad $25 \mathrm{~mm}$ longis ascendentibus. Flores masculi parvuli $2 \mathrm{~mm}$. longi $3 \mathrm{~mm}$. lati in anthesi; tepala exteriora ovata naviculuares apice rotunda; tepala interiora exterioris similia sed aliquantulum angustiora; stamina 6, filamentis multo brevioribus quam anthera ovoideo-globosa. Flos foemineus ignotus.

S i a m: entre Iaksê et Bannhikh. B. Hayata, sin. num.--holotypus in TI.

From the external appearences, this greenbrier is most closely allied to S. siderophylla H.-Mazz. of Yünnan, from which it is distinguished by its always solitary umbels on peduncle not exceeding its petiole. The slender quite smooth stem and the nature of umbel suggest that this may be near to S. glabra Roxb., a well known narrow-leaved one.

17. Smilax chapaensis Gapnepain in Bull. Soc. Bot. Fr. 81: 71 (1934) et in H. Lecomte, F1. Génér. Indo-Chine 6: 766 (1934).

To nk i n: Chapa. B. Hayata, sin. num.-Endemic in Tonkin.

Large liane with densely aculeate, coarse, woody stem.

18. Smilax China Linn. var. taiheiensis (Hayata) T. Koyama in Quart. Journ. Taiwan Museum 10: 9 (1957).

S. verticalis Gagnepain, loc. cit. 81: 74 (1934).

A n n a m: Ba Me Thout. B. Hayata, sin. num., allotype of S. verticalis!-S i a m: Pong Kioh. B. Hayata, sin. num. entre Pong Pa Pow et Pong Kioh. B. Hayata, sin. num.--Formosa, S. China.

18. Smilax ferox Wallich ex A. DC.

A n n a m: Krong Pha. B. Hayata, 784, 979, \& 981-India, S. China.

19. Smilax glaucophylla Klotzsch in Reise Prinz. Wald. Bot. 45, t. 91 (1862); Kitamura in Kihara, Fauna \& F1. Nepal Himal. 96 (1955); T. Koyama in Quart. Journ. Taiwan Mus. 10: (1957).—S. parvifolia Wallich ex Hook f.

Y ün nan: Yünnanfou. B. Hayata, sin. num.-India, Formosa (var.).

This plant resembles $S$. vaginata Decne. at a glance, from which it is distinguished in its somewhat climbing stem and distinctly cirrhose petioles.

20. Smilax hypoglauca Bentham, Fl, Hongk. 369 (1861); A. DC., Monogr. 1: 61 (1878); C. H. Wright in Journ. Linn. Soc. 36: 98 (1903); Norton in Sargent, P1. Wils. 3: 10 (1916).

S i a m; Doi Sutep. B. Hayata, sin. num.-China (Yünnan, Hongkong, Kwantung, \&c.).

New to the flora of Siam, different from its nearest alliance, S. glabra Roxb., in having obtuse-tipped leaf-blades.

21. Smilax lanceaefolia Roxburgh (Hort. Beng. 72. 1814, nomen) F1. Ind. 3: 792 (1832); A. DC.. Monogr. 1 : 57 (1878); Hook. f., F1. Brit. India 6: 308 (1892); Norton in Sargent, P1. Wilson. 3: 11 (1916); Gagnep: in H. Lecomte, loc. cit. 6: 767 (1934).

S i a m: entre Huoi Hai and Nam Tao. B. Hayata, sin. num.; Doi Sutep. B. Hayata, sin. num.-India, China.

This large liane with large herbaceous ovate to lanceolate-ovate leaves is, I think, 
a member of the S. glabra group, which is defined by slender, smooth; terete stem and relatively short peduncle without any scale at the base.

22. Smilax macrophylla Roxburgh (Hort. Beng. 72. 1814, nomen) F1. Ind. 3: 793 (1832); A. DC., Monogr. 1: 193 (1878), excl. var. $\beta$.

S. ovalifolia Roxb., loc. cit. 794; Wight, Icon. 3: t. 809 (1844)-S. retusa Roxb.S. Roxburghii Kunth.

S i a $\mathrm{m}$ : Doi Sutep. B. Hayata, sin. num.-India.

23. Smilax opaca (A. DC.) Norton in Sargent, Pl. Wilson. 3:11 (1916); Gagnep. in H. Lecomte, loc. cit. 6 : 767 (1934); T. Koyama in Quart. Journ. Taiwan Mus. 10 : 19 (1957).

S. lanceaefolia Raxb. var. opaca A. DC., Monogr. 1: 57 (1878)-S. lanceaefolia sensu aust. plur. non Roxb.

S i a m: Nakay. B. Hayata, sin. num.-China, Formosa.

Many authors have confused this with S. lanceaefolia Roxb. It is true that the two strikingly akin when we examine sterile branches, but, although the leaves of S. lanceaefolia are considerably variable, they are rather thin membraneous with minute red-brown spots on the under surface, and shortly caudate at the apex, while in S. opaca, leaves are slightly smaller, somewhat thick membraneous, and relatively suddenly attenuate at the tip. As I mentioned in Quart. Journ. Taiwan Mus. 10: 3-4, quite different state of inflorescences suggests us that these two are better regarded as a member of different section respectively, i. e. S. lanceaefolia is placed in the section Coilanthus including S. China S. glabra etc., and S. opaca belongs to the section Smilax with clearly prophyllate peduncle of umbel, including $S$. perfoliata, $S$ macrophylla, etc.

Some plants of S. opaca from Siam have armed stem, and they are newly described below:

forma aculeata T. Koyama, f. nova caule aculeato.

S i a m: Doi Sutep. B. Hayata, sin. num., type in TI-Banhikh à Taktooug. B. Hayata, sin. num.

24. Smilax perfoliata Loureiro, F1. Cochinch. 622 (1790); Gagnepain in H. Lecomte, F1. Génér. Indo-Chine 6: 761 (1934); T. Koyama in Quart. Journ. Taiwan Mus. 10: 16 (1957).

T o n k i n: Tamdao. B. Hayata, sin. num.-S i a m: Doi Sutep. B. Hayata, sin. num.; entre Bau Do Mo et Khou Vai. B. Hayata, sin. num.-S. China, Formosa, Philippines.

This plant is often confused with Indian S. prolifera Roxb having compound inflorescence. The auricles at the base of petiole is broader in S. perfoliata than in S. prolifera.

25. Smilax bracteata Presl, Rel. Haenk. 1: 131 (1827); T. Koyama in Quart. Journ Taiwan Mus. 10: 18 (1957).

S. stenopetala A. Gray, Bot. of Japan 412 (1859); Gagnep. in H. Lecomte, loc. cit. 
6: 763 (1934).

var. Klotzschii (Kunth) T. Koyama in Quart. Journ. Taiwan Mus. 10: 20 (1957) in adnota-S. Klotzschii Kunth, Enum. P1. 5: 245 (1850); A. DC., Monogr. 1: 188 (1878).

T o n k i n: Chapa. B. Hayata. sin. num.-Malaysia. New. for Indo-China.

var. timorensis (Blume ex A. DC.) T. Koyama in Quart. Journ. Taiwan Mus. 10: 20 (1957) in adnota-S. timorensis Blume ex A. DC., Monogr. 1: 189 (1878).

S i a m: Doi Sutep. B. Hayata, sin. num.-Malaysia.

This is also new to Indo-China. In my previous paper, four eastern Asiatic greenbriers, S. bracteata, S. verruculosa, S. timorensis, and S. Klotzschii, are united into one species, of which the correct name is S. bracteata. S. bracteata originally reported from Luzon, is the same plant with one which we have called S. stenopetala. This species is distributed from the southern Japan through the Ryukyus and Formosa southward to Philippines, but is never reported from the Asiatic continent. $S$. timorensis is, on the one hand, extending from Indo-China southeastward to Timor Island, where the typical S. bracteata does not occur. But, the morphological difference between these two is very slight. S. timorensis is separated from S. bracteata only by more robust habit and somewhat caudate ovate leaves only. It is, therefore, adequate to treat $S$. timorensis as a geographical variant of S. bracteata. Further, an interesting matter is that each of these two has its variations, one having verruculose stem and another with smooth stem within their distributional area respectively. $S$. verruculosa is attributable to S. bracteata, (cf. T. Koyama, 1. c.), while S. Klotzschii corresponds to S. timorensis.

\section{ADDENDA}

Mr. Raymond was kind enough to write to me saying that I should correct the following name of Carex, which I have named after its type locality Mt. Sutep in Siam.

Carex (Filicinae) čoisutepensis 'T. Koyama in Le Nat. Canad. 82; (10-11); 196 (1955), errore doistepensis.

\section{摘 要}

早田教授は 1917 年から 1921 年にわたり, インドシナで植物空採集されたが, 標本は未同定で輠大腊葉 庫汇蔵されている。筆者は一昨年から単子葉植物の同定をしてすでにカヤッリグサ科・ホシクサ科・トゥエン ソウ科等を発表してきたがここに登載した一篇はュリ科学扱つたものである。新種 Disporum tonkinense は葉の形が丸い点ではっきりしたものであり，サルトリバイラ属の標本に Smilax lanceaefolia のたい えよい標本があって，類似品 S. opaca この区別を肯定しえたことは収穫であったと思う。これらの同定を 通じてじょじょに台湾とインドシナのフロラの関係が明らかになるとと, さらに最近ようやく解明されつつ あるマレーシアのフロラとの関連等, 興味深いものがある。 